\title{
Ön Lisans Öğrencilerinin Okul İklimi Algılarının Belirlenmesi
}

\author{
Erdoğan Özdemir ${ }^{*}$, Selden Çepni ${ }^{2}$, Levent İncedere ${ }^{3}$ \\ 1 İstanbul Okan Üniversitesi, Sağlık Hizmetleri Meslek Yüksekokulu, Optisyenlik Programı, İstanbul, Türkiye (ORCID: 0000-0001-7943-8002) \\ ${ }^{2}$ Işık Üniversitesi, Sağlık Hizmetleri Meslek Yüksekokulu, İș Sağlığı ve Güvenliği Programı, İstanbul, Türkiye (ORCID: 0000-0002-8039-4147) \\ ${ }^{3}$ Işık Üniversitesi, Sağlık Hizmetleri Meslek Yüksekokulu, İş Sağlığı ve Güvenliği Programı, İstanbul, Türkiye (ORCID: 0000-0001-5136-9535)
}

(İlk Geliş Tarihi 31 Mart 2020 ve Kabul Tarihi 26 Mayıs 2020)

(DOI: $10.31590 /$ ejosat.710552)

\begin{abstract}
ATIF/REFERENCE: Özdemir, E., Çepni, S. \& İncedere, L. (2020). Ön Lisans Öğrencilerinin Okul İklimi Algılarının Belirlenmesi. Avrupa Bilim ve Teknoloji Dergisi, (19), 272-281.

$\ddot{O} z$

Okul iklimi, eğitimin kalitesini belirleyen ve öğretmenlerle beraber öğrencilerin davranışlarını etkileyen önemli bir olgudur. Bu nedenle eğitimin kalitesi açısından okul iklimi ile ilgili araştırmaların artması gerekmektedir. Bu araştırmada, meslek yüksekokulu öğrencilerinin okul iklimi algılarını belirlemek amaçlanmıştır. Araştırma modeli olarak nicel araştırma yöntemlerinden biri olan betimsel model kullanılmıştır. "Okul İklimi Ölçeği” ile veri toplanan araştırmaya, bir vakıf üniversitesinin meslek yüksekokulunda ve sağlık hizmetleri meslek yüksekokulunda öğrenim görmekte olan "664” öğrenci katılmıştır. Araştırma sonucunda, öğrencilerin en fazla "85.00 puan” alınabilen okul iklimi ölçeğinden aldıkları ortalama puan "56.65” (Ss=14.68) olarak belirlenmiştir. Öğrencilerin okul iklimi ortalama puanları "orta düzey (45-64 puan aralığı) okul iklimi” olarak kategorize edilmiştir. Ayrıca öğrenciler, araştırmanın yapıldığı meslek yüksekokullarını "öğrenme ortamı” ve "iletişımi” açısından yeterli, “okula bağlılık” açısından yetersiz olarak değerlendirmiştir. Öğrencilerin okul iklimi algısının meslek yüksekokulunda öğrenim görülen programa göre değişmediği; sağlık hizmetleri meslek yüksekokulunda ise öğrenim görülen programa göre değiştiği tespit edilmiştir. Son olarak, öğrencilerin yaşları arttıkça okul iklimi algılarının arttığı; sınıf düzeyi arttıkça ise okul iklimi algılarının azaldığı belirlenmiştir. Araştırma bulguları alanyazında yer alan diğer araştırma bulguları ile birlikte değerlendirilerek Türkiye'deki yüksekokullar için öğrencilerinin okul iklimi algılarını artırabilecek önerilerde bulunulmuştur.
\end{abstract}

Anahtar Kelimeler: Meslek yüksekokulu, Okul iklimi, Okula bağlılık, İletişim, Öğrenme ortamı.

\section{Determination of Vocational School Students' School Climate Perceptions}

\begin{abstract}
School climate is an important phenomenon that determines the quality of education and affects the behavior of teachers and students. Therefore, researches on school climate should increase in terms of quality of education. In this study, it is aimed to determine the perception of school climate of vocational school students. Descriptive model, one of the quantitative research methods, was used as the research model. "664" students, who have studied at vocational school and vocational school of health services of a foundation university, participated in the research. Research data was collected with the "School Climate Scale". As a result of the research, the average score of the students from the school climate scale, with the highest score of "85 points", was determined as "56.65" (Ss $=$ 14.68). The school climate average scores of the students were categorized as "intermediate (45-64 score range) school climate". In addition, students evaluated the vocational schools where the research was conducted as sufficient in terms of "learning environment"
\end{abstract}

* Sorumlu Yazar: İstanbul Okan Üniversitesi, Sağlık Hizmetleri Meslek Yüksekokulu, Optisyenlik Programı, İstanbul, Türkiye (ORCID: 0000-00017943-8002), erdogan.ozdemir@okan.edu.tr 
and "communication", and inadequate in terms of "commitment to school". Students' perception of school climate does not change according to the program studied at vocational school. However, it was determined that it changed in the vocational school of health services according to the program studied. Finally, as the ages of the students increase, their perception of the school climate increases; As the grade level increased, perceptions of school climate decreased. The research findings are evaluated in conjunction with other research findings and suggestions were made for vocational schools to increase their students' school climate perceptions.

Keywords: Vocational school, School climate, Commitment to school, Communication, Learning environment.

\section{Giriş}

Günümüz bilgi çağıdır. Bu çağda yeni bilgiler üretme ve teknolojiye ayak uydurma önemli bir beceri haline gelmiştir (Akkuzu ve Uyulgan, 2019). Öğrencilerin bu becerileri kazanabilmesi için okulların, derslerde kullanılan öğretim yöntemleri ve teknikleri, eğitim ortamı, okul iklimi, okula bağlılık ve iletişim gibi birçok açıdan değerlendirilmesi gerekir.

Okul iklimi, öğretmenlerin ve öğrencilerin davranışlarını etkileyen okul ile ilgili bir olgudur (Şahin, 2010). Bir okulu betimleyen ve okulu diğer okullardan farklı kılan bir özellik olarak okul iklimi tanımlanmaktadır (Uğurlu, 2017). Okullar, fiziki oluşum olarak birbirine benzemelerine rağmen sosyal oluşum olarak kendilerine özgüdür. Okulların bu özgün yapısının okul iklimi ile ilgili olduğu bilinmektedir. Okul iklimi öğretmenler ve öğrenciler ile birlikte okul yöneticileri tarafından oluşturulur. Öğretmenlerin, öğrencilerin, yöneticilerin, velilerin ve diğer okul çalışanlarının davranışlarını etkileyen okula ait kişilik olarak okul iklimi ele alınır ve bir kavram olarak okuldaki insan ilişkilerine gönderme yaparak bu ilişkileri ön plana çıkartmaktadır (Ekşi, Türk ve Avcu, 2017). Okulda zaman içinde şekillenen, her zaman görülmeyen değerlerin ve kuralların bütününden oluşur. Bu nedenle bir okulun okul iklimi, okula dişardan gelen kişiler tarafından okulda yer alan kişilere göre daha kolay algılanır (Pritchard, Marrow ve Marshall, 2003).

Okul iklimi, okuldaki birçok değişkenden etkilenir ve onları etkiler. Okulun fiziksel imkanları, okuldaki insanların demografik özellikleri ve kültürel geçmişi, okuldaki iletişimin niteliği, okul normları, değerleri gibi birçok değişkene bağlıdır. Bu değişkenlere bağlı olan okul iklimi, okulun temel unsuru olan öğrencileri de doğrudan etkilemekte ve öğrencilerin davranışlarına yön vermektedir. Pozitif bir okul iklimi, ögrencilerin davranışsal ve duyusal sorunlarını azaltmaktadır. Ayrıca, okul iklimi ile öğrenci başarısı arasında da pozitif bir ilişki vardır (Saraç, 2015). Buna ek olarak olumlu okul iklimi, okulla bağlantılı olan herkesin okulda kendilerini iyi hissetmesine neden olur ve okulda iyi bir iletişim ortamı oluşmasına katkı sağlar (Ekşi, Türk ve Avcu, 2017).

Çok boyutlu bir kavram olan okul iklimi, dört boyutta ele alınmaktadır. Bu boyutlar güvenlik, eğitim-öğretim, bireyler arası ilişkiler ve fiziksel çevredir. Bu boyutlardan biri olan güvenlik boyutu bireylerin kendilerini güvende hissetmeleri ile ilgilidir. Eğitim-öğretim boyutu ile öğretimin kalitesi, öğrenciye çeşitli öğretim olanaklarının sunulması tanımlanmıştır. İlişkiler boyutu ile saygı, iş birliği, öğrenme merkezli olma, mesleki isteklilik ve öğretimde motivasyon kastedilmiştir. Çevre boyutu ise okulun fiziksel olanakları ve okuldaki etkinlikler ile ilgilidir. Başka bir araştırmada boyutlar iletişim, öğrenme ortamı ve okula bağlılık, olarak sınıflandırılmıştır. Buna göre yüksek düzeyde okula bağlılık, iletişim, yeterli donanım, olumlu bir okul iklimi ile sağlanmaktadır (Gündoğan ve Koçak, 2017). ABD’de Birleşik Devletler Eğitim Bölümü Güvenli ve Destekleyici Okullar (Safe and Supportive Schools) programının okul iklimi modelinde ise 3 temel alan ve 13 alt alan tanımlanmıştır. Bu alanlar bağlılık (ilişkiler, farklılıklara saygı, okula katılım), güvenlik (fiziksel güvenlik, duygusal güvenlik, madde kullanımı) ve çevredir (fiziksel çevre, akademik çevre, iyi oluş, disiplin) (Ekşi, Türk ve Avcu, 2017).

Okul ikliminin eğitimin kalitesini belirleyen önemli bir kavram olması nedeni ile birçok araştırmacı, farklı okul türleri için öğrencilerin, öğretmenlerin, yöneticilerin ve velilerin okul iklimi ile ilgili düşüncelerini belirlemiştir (Haynes, Emmons ve Ben-Avie, 1997; Şamdan ve Baskan, 1998; MacNeil, Angus ve Steve 2009; Mitchell, Bradshaw ve Leaf, 2010; Özdemir vd., 2010; Doğan, 2012; Bektaş ve Nalçac1, 2013; Bocchi, Dozza ve Cavrini, 2013; Karakütük vd. 2014; Kılınç, 2014; Şenel ve Buluç, 2016; Saleh vd. 2018; Tofur ve Balıkçı, 2018).

Özdemir vd. (2010), ilköğretim öğrencilerinin okul iklimi ile ilgili alg1 düzeylerini araştırmıştır. Araştırmaya 683 ilköğretim öğrencisi katılmıştır. Araştırma sonucunda cinsiyet ile okul iklimi algısı arasında ilişki bulunmuştur. Araştırmada kız öğrencilerin okul iklimi algılarının, erkek öğrencilere göre daha olumlu olduğu sonucuna ulaşılmıştır. Buna ek olarak bu araştırmada, okul iklimini öğretmenlerin ve yöneticilerinin öğrencileri destekleyici tavırlarının, öğrencilerin öğretim programından memnuniyetinin ve öğrencilerin kendilerini okula ait hissetme duygularının olumlu etkilediği sonucuna ulaşılmıştır. Tüm bunlara ek olarak okuldaki şiddet ile okul iklimi arasında ters yönde bir korelasyon olduğu saptanmıştır. Mitchell, Bradshaw ve Leaf (2010) ise öğrencilerin yanı sıra öğretmenlerin de okul iklimi ile ilgili düşüncelerini karşılaştırmak için 188 beşinci sınıf öğrencisinin ve 90 sınıf öğretmeninin katıldığı bir araştırma gerçekleştirmiştir. Araştırmada veriler “Organizasyon Sağlık Envanteri” ve "Okul Geliştirme Programı Okul İklimi Anketi” ile toplanmıştır. Araştırma sonucunda okul iklimi algısında öğretmenler için sınıf faktörlerinin (zayıf sınıf yönetimi, yıkıcı davranış gösteren öğrenci oranı), öğrenciler için ise okul faktörlerinin (okula gelen ve giden öğrenci sayıları, öğretmen öğrenci ilişkisi, müdür değişikliği) etkili olduğu anlaşılmıştır. Bu iki araştırmada da öğrencilerin okul iklimi algılarında yalnızca sınıf faktörlerinin değil, okul faktörlerinin de etkili olduğu anlaşılmaktadır. Yani okul iklimi ile ilgili öğrenciler yalnızca sınıflarındaki durum ile ilgilenmemektedir. Okul yöneticilerinin davranışları ve okula gelen veya okuldan giden öğrenci oranları ile de ilgilenmektedir. Bu bulgular, öğrencilerin okul iklimini ders gördükleri sınıfın dışına çıkarak geniş bir perspektifte değerlendirdiğini göstermektedir.

Doğan (2012), ortaöğretim öğrencilerinin okul iklimi ile ilgili algı düzeylerini araştırmıştır. Araştırmaya 1246 öğrenci katılmıştır. Araştırmada veriler "Okul İklimi Ölçeği”" ile toplanmıştır. Araştırmada, öğrencilerin okul iklimi algıları ile öğrencilerin sınıf düzeyi, ailedeki birey sayısı, ailelerinin geliri, ailelerinin eğitim düzeyi arasında pozitif ilişki olduğu belirlenmiştir. Tüm bunlara ek olarak, bu araştırmada okul iklimi ile ilgili görüşlerin cinsiyete göre farklılık gösterdiği tespit edilmiştir. Araştırmada kız öğrencilerin erkek öğrencilere göre ilişkiler boyutunda okul iklimini daha olumlu değerlendirdiği ifade edilmiştir. Özdemir vd. (2010)'de okul iklimi ve cinsiyet ile ilgili benzer bulgulara ulaşmıştır. Bu bulgular kız öğrencilerin erkek öğrencilere göre okullarından daha fazla memnun olma 
eğiliminde olduğunu göstermektedir. Saleh vd. (2018) ise üniversite öğrencilerinin okul çevresi algılarını belirlemek için bir araştırma gerçekleştirmiştir. 497 kişinin katıldığı araştırmada veriler “Dundee Hazır Eğitim Ortamı Ölçeği” ile toplanmıştır. Araştırma sonucunda öğrencilerin genel olarak eğitim ortamına ilişkin olumlu algılarının olumsuz algılarından daha fazla olduğu tespit edilmiştir. Bir başka ifade ile öğrencilerin genel olarak okul iklimi algılarının ortalama düzeyde olduğu kabul edilmiştir. Ayrıca yaş, evlilik ve sınıf düzeyi değişkenleri içinde gruplar arasında tek farklılığa neden olan değişkenin, sınıf düzeyi olduğu tespit edilmiştir. İkinci sınıfa giden öğrencilerin okul çevresi ile ilgili memnuniyet algılarının üçüncü, dördüncü, beşinci ve intörn öğrencilere göre daha yukarıda olduğu belirlenmiştir. Araştırmanın bu sonucu, Doğan (2012)'ın okul iklimi ve sınıf düzeyi arasındaki ilişkiye yönelik bulguları ile çelişmektedir. Bu iki araştırmanın sonuçları bir arada değerlendirildiğinde, öğrencilerin ortaöğretim düzeyinde üst sınıfa geçtikçe okul iklimi algılarının arttığı, üniversite düzeyinde ise üst sınıfa geçtikçe okul iklimi algılarının azaldığı şeklinde yorumlanabilir. Bir başka araştırmada ise Şamdan ve Baskan (2019) öğrencilerin okulla ilgili memnuniyet düzeylerini araştırmıştır. Araştırmaya yaşları 11 ile 15 arasında değişen üç farklı ülkede öğrenim gören 16374 öğrenci katılmıştır. Araştırmada veri toplama aracı olarak "Okul Çağı Çocuklarında Sağlık Davranışı Anketi” kullanılmıştır. Araştırma sonuçlarına göre öğrencilerin yaşı arttıkça okuldan daha az memnun oldukları sonucuna ulaşılmıştır. Bocchi, Dozza ve Cavrini (2013) ise diğer araştırmacılardan farklı olarak okul iklimi ile ilgili öğretmenlerin yanı sıra velilerin görüşlerini incelemiştir. Araştırmaya bir okulda öğrenim gören 3862 anaokulu, ilkokul, ortaokul ve lise öğrenci velisi ile 1183 öğretmen katılmıştır. Araştırmada, velilerin ve öğretmenlerin okul iklimi ile ilgili memnuniyet düzeyinin yüksek olduğu sonucuna ulaşılmıştır. Ayrıca sınıf düzeyi arttıkça, velilerin okul iklimi ile ilgili memnuniyet düzeyinin azaldığı sonucuna ulaşılmıştır. Öğretmenlerin ise derslerine girdikleri sınıf düzeyine göre okul iklimi ile ilgili memnuniyet düzeyleri arasında bir fark bulunamamiştır.

Bektaş ve Nalçacı (2013) ilköğretim öğrencilerinin okul iklimi ile akademik başarısı arasındaki ilişkiyi araştırmıştır. Araştırmaya 598 ilköğretim sekizinci sınıf öğrencisi katılmıştır. Öğrencilerin “Okul İklimi Ölçeği Puanları” ile "Ulusal Seviye Belirmeme Sınavı" puanları arasındaki ilişki incelenmiştir. Çalışma sonuçlarına göre, alanyazından farklı olarak öğrencilerin okul iklimi ölçeğinin boyutları olan destekleyici güvenli öğrenme ortamı, öğretici davranışları ve başarı odaklılık algıları ile akademik başarıları arasında istatistiksel olarak anlamlı bir ilişki olmadığı görülmüştür. MacNeil, Angus ve Steve (2009)'de öğrencilerin akademik başarıları ile okul iklimi arasındaki ilişkiyi araştırmıştır. Araştırmada veriler “Örgüt Sağlığı Envanteri” ile toplanmıştır. Sağlıklı öğrenme ortamı olan okulların diğer okullara göre standart sınavlarda daha başarılı olduğu araştırmada anlaşılmıştır. Haynes, Emmons ve Ben-Avie (1997) okul ikliminin eğitim çıktılarıyla ilişkisini incelemiştir. Araştırmada okul ikliminin, öğrencilerin psikolojik ve eğitimsel gelişimine etkisi olduğu vurgulanmış ve öğrencilerin okulda yaşadığı etkileşimlerin ve deneyimlerin, öğrencilerin akademik başarılarına ve daha sonraki yaşamlarındaki psikososyal uyumlarına olumlu etkisi olduğu ifade edilmiştir.

$\mathrm{Bu}$ araştırmalara, ek olarak öğrencilerin yanı sıra öğretmenlerin aralarındaki iletişimin, okulda yapılan etkinliklerin, yönetici davranışlarının ve okul büyüklüğünün okul iklimi ile ilişkisi de araştırılmıştır (Kılınç, 2014; Şenel ve Buluç, 2016; Doğan, 2012; Tofur ve Balıkçı, 2018; Karakütük vd. 2014). Bu araştırmalarda elde edilen sonuçlar ise şu şekildedir; kısıtlayıcı okul ikliminde çalışan öğretmenler liderlik rolü üstlenmemektedir. Bu durum okul iklimini olumsuz yönde etkilemektedir (Kılınç, 2014). Okulda yapılan etkinlikler ile öğretmenler arası güçlü iletişim ve yardımlaşma okul iklimini olumlu etkilemektedir (Şenel ve Buluç, 2016). Öğretmenlerin cinsiyeti ve yaşı ile öğretmenler arası iletişimin niteliği okul iklimi üzerinde etkilidir (Doğan, 2012). Bir kurumda yöneticilerin astlara değer vermesi, eğitime önem verilmesi, çalışan iletişimi, paydaşların kararlara katılımı, adil yönetim, vizyon ve misyonun tanılanması, çalışanların görev ve sorumluluklarının farkında olması, aile ortamının olması okul iklimini pozitif yönde etkilemektedir. Ayrıca bir okulda öğrenim gören öğrenci sayısı az ise okuldaki öğrencilerin okul iklimi ile ilgili olumlu algıları artmaktadır (Karakütük vd. 2014).

Alanyazın incelendiğinde, okul ikliminin birçok değişkenden etkilenen karmaşık bir kavram olduğu anlaşılmaktadır. Okul iklimi ile ilgili bu araştırmalar bir bütün olarak ele alındığında okul iklimini olumlu etkileyen değişkenler şu şekilde sıralanabilir: Okulun güvenli olması, öğrencinin kendini okula ait hissetmesi, okuldaki ve sınıftaki yönetimin başarılı olması, okulun genelinde bir istikrar algısının oluşması, öğrencilere adil davranılması, okulda sağlıklı iletişim olması, öğrencilerin başarısının desteklenmesi, okuldaki deneyimlerin niteliği ve öğretim ortamının niteliği şeklindedir. Bunlara ek olarak araştırmalarda okul ikliminin öğrencilerin cinsiyeti, sınıf düzeyi, akademik başarısı, yaşı, aile yapısı ile de ilişkili olduğu belirlenmiştir. Okul iklimi ile ilgili değişkenlerin ve bu değişkenlerin etkilerinin belirlenmesi için öğrencilerin, öğretmenlerin, yöneticilerin ve velilerin görüşlerini incelemeye yönelik araştırmaların artması ve çeşitlenmesi gerekmektedir. Bu araştırmada, yüksekokul öğrencilerinin okul iklimi algılarını belirlemek ve bu sonuçlar 1şığında yüksekokullarda okul ikliminin iyileştirilmesi için önerilerde bulunmak amaçlanmıştır. Bu araştırmada, araştırmanın amacına uygun olarak şu problemlere yanıt aranmıştır: i) Meslek yüksekokulu öğrencilerinin okul iklimi algıları hangi düzeydedir? ii) Meslek yüksekokulu öğrencilerinin okul ikliminin alt boyutları ile ilgili algıları hangi düzeydedir? ii) Meslek yüksekokulu programları açısından okul iklimi puanları arasında anlamlı bir fark var mıdır? iii) Sağlık hizmetleri meslek yüksekokulu programları açısından okul iklimi puanları arasında anlamlı bir fark var mıdır? iv) Sağlık hizmetleri meslek yüksekokulu öğrencileri ile meslek yüksekokulu öğrencilerinin okul iklimi ile ilgili puanları arasında anlamlı bir fark var mıdır? v) Öğrencilerin sınıf düzeyine göre okul iklimi puanları arasında anlamlı bir farklılık var mıdır? vi) Öğrencilerin yaşına göre okul iklimi puanları arasında anlamlı bir farklılık var mıdır?

\section{Materyal ve Metot}

$\mathrm{Bu}$ araştırmada, ön lisans programlarında öğrenim gören öğrencilerin okul iklimi algıları belirlenmiştir. Araştırma modeli olarak nicel araştırma yöntemlerinden biri olan betimsel model kullanılmıştır. Araştırmanın örnekleminin belirlenmesinde uygun örnekleme yöntemi kullanılmıştır. Araştırmada veriler “Okul İklimi Ölçeği” ile toplanmıştır. Öğrencilerin vermiş olduğu yanıtlar betimsel istatistik ve fark testleri kullanılarak analiz edilmiştir. 


\section{1. Örneklem}

Araştırmanın örnekleminin belirlenmesinde, uygun örnekleme yöntemi kullanılmıştır. Örneklemin belirlenmesinde bu yöntemin seçilme nedeni araştırmaya hız kazandırmasıdır (Kılıç, 2013). Bu yöntemde yanlılık fazla olduğu için araştırmanın örneklemi büyük seçilmiştir. Araştırmanın örneklemini Türkiye'deki bir vakıf üniversitesinin ön lisans programlarında öğrenim gören “664” öğrenci oluşturmaktadır. Anket ile ilgili demografik bilgiler bölümünü dolduran öğrencilerin beyanlarına göre 2018-2019 güz yarıyılında öğrenim gören bu öğrencilerin \%27,0’1 meslek Yüksekokulu; \%73,0’1 sağlık hizmetleri meslek yüksekokulu öğrencisidir. Ayrıca araştırmaya katılan öğrencilerin \%51,0’1 birinci sınıf; \%49,0’’ ikinci sınıf öğrencisidir. Bu öğrencilerin \%92,0’1 17-25; \%4,0’1 26-34; $\% 4,0$ ’ ise 35 ve üzeri yaş aralığındadır.

\subsection{Veri Toplama Araci}

Çalışmada veri toplama aracı olarak Terzi (2015) tarafından üniversitedeki öğrencilerin okul iklimi algılarını ölçmek için geliştirilen “Okul İklimi Ölçeği” kullanılmıştır. Ölçek beşli Likert (hiçbir zaman, nadiren, bazen, çoğunlukla, her zaman) tipindedir ve 17 maddeden oluşmaktadır. Ölçek maddeleri üç faktör altında toplanmıştır. Ölçekte yer alan bu faktörler okula bağlılık, iletişim ve öğrenme ortamıdır. Terzi (2015) tarafından ölçeğin güvenilirlik ve geçerlilik çalışmaları yapılmıştır. Ölçeğin maddeleri için faktör yük değerleri .46 ile .76 arasında, madde-toplam korelasyonları ise .34 ile .60 arasında değişmektedir. Ölçeğin tümü için hesaplanan Cronbach alpha katsayısı ise .90 'dir.

\subsection{Verilerin Analizi}

Ölçek verileri şu şekilde puanlanmıştır; hiçbir zaman yanıtı "1 puan”, nadiren yanıtı "2 puan”, bazen yanıtı "3 puan”, çoğunlukla yanıtı "4 puan" ve her zaman yanıtı "5 puan". Bu puanlamaya göre ölçekten en fazla "85 puan” alınabilmektedir. Öğrencilerin ölçek puanları “JASP 0.10.2.0” programına aktarılmıştır. Verilerin analizinde ilk olarak betimsel istatistik kullanılmıştır.

Öğrencilerin her bir soru ve faktör için yanıtlara dağılım yüzdeleri incelenmiştir. Buna ek olarak öğrencilerin ortalama puanları, standart sapmaları hesaplanmıştır. Ölçek puanları değerlendirilirken 0-44 aralığındaki puanlar "düşük düzeyde okul iklimi algısı", 4564 aralığındaki puanlar “orta düzeyde okul iklimi algısı”, 65-85 aralığındaki puanlar "yüksek düzeyde okul iklimi algısı” olarak kabul edilmiştir. Tüm bunlara ek olarak puan ortalamaları arasındaki farkları analiz etmek için fark testlerinden yararlanılmıştır. Normallik testi olan "Shapiro-Wilk Testi” kullanılmıştır. Veriler normal dağılım gösterdiği için "İlişskisiz Örneklemler için Tek Yönlü Varyans Analizi” uygulanmıştır. Gruplar arasındaki farkların hangi grup lehine olduğunu belirlemek için ise "Scheffe Çoklu Karşılaştırma Tekniği” kullanılmıştır.

\section{Bulgular}

Bu bölümde araştırmanın betimsel istatistik ve fark testi sonuçlarına yer verilmiştir.

\subsection{Betimsel İstatistik ile Analiz Edilen Bulgular}

Tablo 1'de yanıtların ölçek faktörlerine ve faktör maddelerine dağılım yüzdeleri yer almaktadır.

Tablo 1. Öğrenci yanıtlarının faktörlere ve maddelere dă̆llım yüzdeleri

\begin{tabular}{|c|c|c|c|c|c|}
\hline Faktör ve Maddeler & Hiçbir Zaman & Nadiren & Bazen & Çoğunlukla & Her zaman \\
\hline Okula Băğlılık & 16.1 & 19.5 & 31.3 & 19.0 & 15.5 \\
\hline Kendimi okulun bir parçası gibi görüyorum. & 13.0 & 16.3 & 34.0 & 20.3 & 15.5 \\
\hline $\begin{array}{l}\text { Üniversite sınavına gireceklere okulumu tercih } \\
\text { etmelerini öneririm. }\end{array}$ & 19.7 & 20.2 & 28.9 & 16.9 & 14.2 \\
\hline Okulumu her ortamda savunurum. & 13.4 & 18.8 & 33.6 & 20.0 & 13.7 \\
\hline Okuduğum okulun öğrencisi olmak ayrıcalıktır. & 17.3 & 22.1 & 30.1 & 18.4 & 11.3 \\
\hline Okulum hayata dair beklentilerimi karşılamaktadır. & 17.3 & 20.2 & 30.0 & 19.6 & 11.4 \\
\hline İletişim & 6.3 & 9.9 & 21.2 & 27.7 & 33.8 \\
\hline Öğretim elemanları iletişime her zaman açıktır. & 3.3 & 7.7 & 13.9 & 31.9 & 42.3 \\
\hline $\begin{array}{l}\text { Ögretim elemanları beni dinlemek için gönüllü } \\
\text { davranır. }\end{array}$ & 4.4 & 6.9 & 19.6 & 28.9 & 39.2 \\
\hline $\begin{array}{l}\text { Bir problemim olduğunda öğretim elemanlarına } \\
\text { danışmaktan çekinmem. }\end{array}$ & 4.7 & 7.5 & 17.0 & 24.4 & 45.3 \\
\hline $\begin{array}{l}\text { Bir problem yaşadiğımda ögretim elemanları } \\
\text { yardım için elinden geleni yapar. }\end{array}$ & 3.8 & 8.0 & 19.0 & 30.0 & 38.1 \\
\hline $\begin{array}{l}\text { Okul yönetimi, öğrencileri uygulamalar hakkında } \\
\text { zamanında bilgilendirir. }\end{array}$ & 10.5 & 14.9 & 29.4 & 25.6 & 18.5 \\
\hline $\begin{array}{l}\text { Uygulamalarla ilgili düşüncelerimi okul yönetimine } \\
\text { yeterli düzeyde aktarabilirim. }\end{array}$ & 10.8 & 14.2 & 28.5 & 25.5 & 19.3 \\
\hline Ögrenme Ortamı & 11.0 & 15.7 & 26.2 & 27.7 & 18.5 \\
\hline
\end{tabular}




\begin{tabular}{|c|c|c|c|c|c|}
\hline $\begin{array}{l}\text { Okulum mesleğimle ilgili bilgi ve becerileri yeterli } \\
\text { düzeyde kazandırmaktadır. }\end{array}$ & 10.1 & 13.6 & 23.6 & 29.4 & 22.9 \\
\hline $\begin{array}{l}\text { Okulumda ögrenci merkezli bir ögrretim anlayışı söz } \\
\text { konusudur. }\end{array}$ & 14.0 & 16.0 & 27.4 & 26.2 & 14.9 \\
\hline $\begin{array}{l}\text { Okulum öğrenme için yeterli fiziksel donanıma } \\
\text { sahiptir. }\end{array}$ & 15.2 & 22.3 & 27.0 & 22.4 & 12.3 \\
\hline $\begin{array}{l}\text { Okulumda var olan donanıma kolaylıkla erişebilir } \\
\text { ve kullanabilirim. }\end{array}$ & 11.4 & 17.8 & 28.3 & 25.5 & 16.0 \\
\hline $\begin{array}{l}\text { Yeter ki ögrenmek isteyeyim. Okulumda bir firsatını } \\
\text { mutlaka bulurum. }\end{array}$ & 8.3 & 14.5 & 24.4 & 29.5 & 22.4 \\
\hline $\begin{array}{l}\text { Derslerde üst düzey (eleştirel, yaratıcı vb.) } \\
\text { düşünmeye ăgırlık verilir. }\end{array}$ & 6.8 & 10.2 & 26.4 & 33.1 & 22.7 \\
\hline Genel Ortalama & 11.1 & 15.0 & 26,2 & 24.8 & 22.6 \\
\hline
\end{tabular}

Tablo 1 incelendiğinde öğrencilerin ölçeğin bütünü için "bazen” yanıtında toplandıkları anlaşılmaktadır. Yanıtların genel dağılımı incelendiğinde ise öğrencilerin okul iklimi ile ilgili "çoğunlukla" ve "her zaman" şeklindeki olumlu yanıt yüzdelerinin fazla olduğu anlaşılmaktadır. Tablo 1'deki yanıt dağılımı faktörlere göre incelendiğinde ise öğrencilerin "okula bağlılık" faktörü içinde "bazen" yanıtında toplandıkları anlaşılmaktadır. Bununla birlikte "hiçbir zaman” ve "nadiren” yanıtlarının fazlalığı dikkat çekmektedir. Bu faktör için öğrencilerin olumsuz yanıt yüzdesinin en fazla olduğu madde ise şudur: "Üniversite sınavına gireceklere okulumu tercih etmelerini öneririm". "İletişim" faktörü ile ilgili yanıtlar incelendiğinde öğrencilerin "her zaman" yanıtında toplandıkları anlaşılmaktadır. Bununla birlikte "çoğunlukla" yanıtının fazlalığı dikkat çekmektedir. Bu faktör için öğrencilerin olumlu yanıt yüzdesinin en fazla olduğu madde şudur: "Bir problemim olduğunda öğretim elemanlarına danışmaktan çekinmem." "Öğrenme ortamı" faktörü ile ilgili yanıtlar incelendiğinde, öğrencilerin "çoğunlukla" yanıtında toplandıkları anlaşılmaktadır. Bununla birlikte "bazen" yanıtlarının fazlalığı dikkat çekmektedir. Bu faktör için öğrencilerin olumlu yanıt yüzdesinin en fazla olduğu madde şudur: "Yeter ki öğrenmek isteyeyim. Okulumda bir firsatını mutlaka bulurum.” Bu verilere ek olarak öğrencilerin ölçekten aldıkları ortalama puan 56,65 ; standart sapma ise 14,68 dir.

\subsection{Fark Testleri ile Analiz Edilen Bulgular}

$\mathrm{Bu}$ bölümde ilk olarak verilerin normal dağılım durumu incelenmiştir. Ardından meslek yüksekokulu programlarının ve sağlık hizmetleri meslek yüksekokulu programlarının ayrı ayrı ortalama puanları arasındaki farklılık incelenmiştir.

\subsubsection{Normallik Testi Sonuçları}

Tablo 2'de Shapiro-Wilk normallik testi sonuçları yer almaktadır.

Tablo 2. Ölçek maddeleri için Shapiro-Wilk Testi sonuçları

\begin{tabular}{|c|c|c|c|c|c|c|c|c|c|c|c|}
\hline Soru & İstatistik & S.d & $\mathbf{p}$ & Çarpıklık & Basıklık & Soru & İstatistik & S.d & p & Çarpıklık & Basıklık \\
\hline 1 & ,919 & 664 & ,000 &,- 154 &,- 721 & 10 & ,835 & 664 & ,000 & $-1,015$ & ,543 \\
\hline 2 & ,906 & 664 & ,000 & ,112 & $-1,020$ & 11 & ,914 & 664 & ,000 &,- 337 &,- 667 \\
\hline 3 & ,919 & 664 & ,000 &,- 054 &,- 773 & 12 & ,914 & 664 & ,000 &,- 394 &,- 625 \\
\hline 4 & ,921 & 664 & ,000 & ,070 &,- 854 & 13 & ,919 & 664 & ,000 &,- 278 &,- 805 \\
\hline 5 & ,926 & 664 & ,000 &,- 019 &,- 841 & 14 & ,922 & 664 & ,000 &,- 025 &,- 921 \\
\hline 6 & ,896 & 664 & ,000 &,- 4654 &,- 727 & 15 & ,920 & 664 & ,000 &,- 247 &,- 759 \\
\hline 7 & ,805 & 664 & ,000 & $-1,191$ & -942 & 16 & ,902 & 664 & ,000 &,- 483 &,- 586 \\
\hline 8 & ,831 & 664 & ,000 & $-1,026$ & ,531 & 17 & ,891 & 664 & ,000 &,- 637 &,- 166 \\
\hline 9 & ,804 & 664 & ,000 & $-1,095$ & ,465 & & & & & & \\
\hline
\end{tabular}

Tablo 2'de yer alan bulgulara göre veriler normal dağılım göstermemektedir $(\mathrm{p}<.05)$. Fakat skewness ve kurtisos değerleri -2 ile +2 arasında yer almaktadır. Bu nedenle değişkenlerin normal dağılım gösterdiği kabul edilmiş (George ve Mallery, 2010) ve verilerin analizinde parametrik testler kullanılmıştır.

\subsubsection{Meslek Yüksekokulu Programlarının Okul İklimi Puanlarının Karşılaştırılması}

Tablo 3'te meslek yüksekokulu programlarının ortalama puanları yer almaktadır. 
Tablo 3. Meslek Yüksekokulu programlarının ortalama puanları

\begin{tabular}{l|c|c|c}
\hline Program & N & Ortalama Puan & Standart Sapma \\
\hline Grafik Tasarımı & 53 & 58.17 & 12.57 \\
\hline Moda Tasarımı & 13 & 55.23 & 13.04 \\
\hline Mimari Restorasyon & 80 & 58.16 & 16.24 \\
\hline Radyo Televizyon & 11 & 55.73 & 12.74 \\
\hline Toplam & 157 & 57.75 & 14.51 \\
\hline \multicolumn{3}{|c}{ Olçekten alınabilecek en yüksek ortalama puan: 85 'tir. N kişi saylsıdır. }
\end{tabular}

Tablo 3'te meslek yüksekokulu programı öğrencilerinin ölçekten aldığı ortalama puanlar yer almaktadır. Bu sonuçlara göre meslek yüksekokulu programlarında öğrenim gören öğrencilerin okul iklimi algıları orta düzey (45-64 puan aralığı) olarak kategorize edilmiştir.

Meslek yüksekokulu programlarına göre öğrencilerin puanları arasındaki farklılığın önem durumunu belirlemek için Levene testi uygulanmıştır. Bu testin sonuçlarına göre grupların varyanslarının eşitliği kabul edilmiştir (p>.05). Bu sayede tek yönlü varyans analizi için ön koşul sağlanmıştır.

Tablo 4. Meslek yüksekokulu programları için tek yönlü varyans analizi sonuçları

\begin{tabular}{l|l|l|l|l|l}
\hline & Kareler Toplamı & sd & Kareler Ortalaması & F & p \\
\cline { 1 - 5 } Gruplar Arası & 150.463 & 3 & 50.154 & .235 & .872 \\
\cline { 1 - 4 } Içi & 32700.849 & 153 & 213,731 & & \\
\cline { 1 - 3 } Toplam & 32851.312 & 156 & & & \\
\hline
\end{tabular}

Varyans analizi sonucunda elde edilen F değeri .235 olarak hesaplanmıştır. Grupların ortalama puanları arasındaki fark (p<.05) anlamsız bulunmuştur.

\subsubsection{Să̆lık Hizmetleri Meslek Yüksekokulu Programlarının Okul İklimi Puanlarının Karşılaştırılması}

Tablo 5'te sağlık hizmetleri meslek yüksekokulu programlarının ortalama puanları yer almaktadır.

Tablo 5. Să̆lık hizmetleri meslek yüksekokulu programlarının ortalama puanları

\begin{tabular}{l|c|c|c}
\hline Program & $\mathbf{N}$ & Ortalama Puan & Standart Sapma \\
\hline Ameliyathane Hizmetleri & 76 & 52.39 & 14.109 \\
\hline İs Să̆lı̆̆ı ve Güvenliği & 28 & 64.54 & 11.955 \\
\hline Odyometri & 74 & 53.35 & 14.371 \\
\hline Optisyenlik & 41 & 66.20 & 11.426 \\
\hline Tıbbi Dokümantasyon & 64 & 55.64 & 14.386 \\
\hline Tıbbi Görüntüleme & 100 & 55.03 & 14.597 \\
\hline Tıbbi Laboratuvar & 50 & 50.64 & 13.779 \\
\hline Toplam & 433 & 55.54 & 14.576 \\
\hline Ölçekten alınabilecek en yüksek ortalama puan: $85^{\prime}$ 'tir. N kişi sayısıdır.
\end{tabular}

Tablo 5’te sağlık hizmetleri meslek yüksekokulu programlarındaki öğrencilerin ölçekten aldığı ortalama puanlar yer almaktadır. Bu sonuçlara göre "optisyenlik" ve "iş sağlı̆̆ı ve güvenliği” programı öğrencilerinin okul iklimi puanları yüksek düzey okul iklimi algısı (65-85 puan aralığı) olarak kategorize edilmiş̧tir. Diğer programlar ise orta düzey okul iklimi algısı (45-64 puan aralığı) olarak kabul edilmiştir.

Sağlık hizmetleri meslek yüksekokulu programlarına göre öğrencilerin okul iklimi puanları arasındaki farklılığın önem durumunu belirlemek için Levene testi uygulanmıştır. Test sonuçlarına göre grupların varyanslarının eşitliği kabul edilmiştir ( $\mathrm{p}>.05$ ). Bu sayede tek yönlü veryans analizi yapabilmek için ön koşul sağlanmıştır.

Tablo 6. Sağlık hizmetleri meslek yüksekokulu programları için tek yönlü varyans analizi sonuçları

\begin{tabular}{l|c|c|c|c|c}
\hline & Kareler Toplamı & sd & Kareler Ortalaması & F & p \\
\hline Gruplar Arası & 9254.105 & 6 & 1542.351 & & \\
\cline { 1 - 4 } Grup Içi & 82523.590 & 426 & 193.717 & \multirow{2}{*}{7.962} & \multirow{2}{*}{000} \\
\cline { 1 - 4 } Toplam & 91777.695 & 432 & & & \\
\hline
\end{tabular}

Varyans analizi sonucunda elde edilen F değeri 7.962 olarak hesaplanmıştır. Gruplar arasındaki ortalama puanlar arasındaki fark $\mathrm{p}<.05$ anlamlılık düzeyinde anlamlı bulunmuştur. Gerçekleştirilen Scheffe çoklu karşılaştırma analizi sonuçları aşağıdaki tabloda yer almaktadır. 
Tablo 7. Tek yönlü varyans analizi (ANOVA) sonrası post-hoc Scheffe testi sonuçlarl

\begin{tabular}{|c|c|c|c|c|c|c|c|}
\hline Program (i) & Program (j) & Ortalama Farkı & $\mathbf{p}$ & Program (i) & Program (j) & Ortalama Farkı & $\mathbf{p}$ \\
\hline \multirow[t]{6}{*}{ Amel. Hiz. } & İş Sağ. G & $-12,141 *$ & ,018 & \multirow[t]{6}{*}{ Tıbbi Dök. } & Amel. Hiz. & 3,246 & ,929 \\
\hline & Odyomet. &,- 967 & 1,000 & & İş Sağ. G & $-8,895$ & ,244 \\
\hline & Optisyen. & $-13,800^{*}$ & ,000 & & Odyomet. & 2,289 & ,998 \\
\hline & Tibbi Dök. & $-3,246$ & ,929 & & Optisyen. & $-10,554^{*}$ & ,027 \\
\hline & Tibbi Gör. & $-2,635$ & ,956 & & Tibbi Gör. & 611 & 1,000 \\
\hline & Tibbi Lab. & 1,755 & ,998 & & Tibbi Lab. & 5,001 & ,727 \\
\hline \multirow[t]{6}{*}{$\dot{I}$ Is Săg. G. } & Amel. Hiz. & $12,141^{*}$ & ,018 & \multirow[t]{6}{*}{ Tıbbi Gör. } & Amel. Hiz. & 2,635 & ,956 \\
\hline & Odyomet. & $11,184 *$ &, 043 & & İş Sağ. G & $-9,506$ &, 119 \\
\hline & Optisyen. & $-1,659$ & 1,000 & & Odyomet. & 1,679 & ,996 \\
\hline & Tibbi Dök. & 8,895 & ,244 & & Optisyen. & $-11,165^{*}$ & ,005 \\
\hline & Tibbi Gör. & 9,506 & ,119 & & Tıbbi Dök. &,- 611 & 1,000 \\
\hline & Tibbi Lab. & $13,896 *$ & ,007 & & T1bbi Lab. & 4,390 & ,768 \\
\hline \multirow[t]{6}{*}{ Odyomet. } & Amel. Hiz. & ,957 & 1,000 & \multirow[t]{6}{*}{ Tibbi Lab. } & Amel. Hiz. & $-1,755$ & ,998 \\
\hline & İş Sağ. G. & $-11,184^{*}$ &, 043 & & İş Sağ. G. & $-13,896^{*}$ & ,007 \\
\hline & Optisyen. & $-12,844$ & ,001 & & Odyomet. & $-2,711$ & ,980 \\
\hline & Tıbbi Dök. & $-2,289$ & ,988 & & Optisyen. & $-15,555^{*}$ & , 000 \\
\hline & T1bbi Gör. & $-1,679$ & ,996 & & Tıbbi Dök. & $-5,001$ &, 727 \\
\hline & Tibbi Lab. & 2,711 & ,980 & & Tıbbi Gör. & $-4,390$ & ,768 \\
\hline \multirow[t]{6}{*}{ Optisyen. } & Amel. Hiz. & $13,800 *$ & ,000 & & & & \\
\hline & İş Sağ. G & 1,659 & 1,000 & & & & \\
\hline & Odyomet. & $12,844 *$ &, 001 & & & & \\
\hline & Tibbi Dök. & $10,554^{*}$ & ,027 & & & & \\
\hline & Tibbi Gör. & $11,165^{*}$ & ,005 & & & & \\
\hline & Tibbi Lab & $15,555^{*}$ & ,000 & & & & \\
\hline
\end{tabular}

.05 seviysinde fark anlamlı $p<.05$

Tablo 7'de (*) ile ifade edilen ortalama farklar anlamlı fark çıkan verileri belirtmektedir. Tablo 7 incelendiğinde programlar arasındaki en büyük farklılığın "optisyenlik" ve "iş sağlığı güvenliği programı" ile "tıbbi laboratuvar programı "arasında "optisyenlik" ve "iş sağlığı güvenliğii” lehine olduğu görülmektedir. Yukardaki tablo incelendiğinde diğer önemli bir farklılığın ise "optisyenlik" programı ile "ameliyathane hizmetleri" arasında "optisyenlik" programı lehine olduğu anlaşılmaktadır.

\subsubsection{Yüksekokulların Okul İklimi Puanlarının Karşılaştırılması}

Tablo 8'de sağlık hizmetleri meslek yüksekokulu ile meslek yükssekokulu ortalama puanları arasındaki farklılık ile ilgili bulgular yer almaktadir.

Tablo 8. Meslek yüksekokulu ve sağlık hizmetleri meslek yüksekokulu ortalama puanları

\begin{tabular}{l|c|c|c|l|l}
\hline Yüksekokul & N & Ortalama & Standart Sapma & t & p \\
\hline Meslek yüksekokulu & 233 & 57.75 & 14.70 & \multirow{2}{*}{0.777} & \multirow{2}{*}{.437} \\
\cline { 1 - 5 } Să̆lk hizmetleri meslek yüksekokulu & 366 & 55.54 & 14.64 & & \\
\hline$p>0.05$ fark anlamlı değil
\end{tabular}

Tablo 8 incelendiğinde sağlık hizmetleri meslek yüksekokulu ile meslek yüksekokulu öğrencilerinin puanları arasında anlamlı bir farklılık olmadığı anlaşılmaktadır.

\subsubsection{Yüksekokulların Okul İklimi Puanlarının Sınıf Düzeyine Göre Karşılaştırılması}

Tablo 9'da ön lisans öğrencilerinin sınıf düzeyine göre ortalama puanları yer almaktadır.

Tablo 9. Ön Lisans Öğrencilerinin Sınıf Düzeyine Göre Ortalama Puanları

\begin{tabular}{l|l|l|l|l|l}
\hline Yüksekokul & $\mathbf{N}$ & Ortalama & Standart Sapma & t & p \\
\hline Birinci sınıf & 305 & 59.13 & 13.51 & 5.391 & .001 \\
\cline { 1 - 3 } Íkinci sınıf & 291 & 52.82 & 15.04 & & \\
\hline$p>0.05$ fark anlaml değil
\end{tabular}


Tablo 9 incelendiğinde her iki grubunda orta düzey okul iklimi algısı (45-64 puan aralığı) kategorisinde yer aldığı anlaşılmaktadır. Buna ek olarak birinci ve ikinci sınıf öğrencilerinin ortalama puanları arasındaki farkın birinci sınıf lehine anlamlı olduğu anlaşılmaktadır.

\subsubsection{Yüksekokulların Okul İklimi Puanlarının Yaşa Göre Karşılaştırılması}

Tablo 10’da ön lisans öğrencilerinin yaş aralığına göre ortalama puanları yer almaktadır.

Tablo 10. Yaş aralı̆̆ına göre ortalama puanlar

\begin{tabular}{|c|c|c|c|}
\hline Yaş Aralığı & $\mathbf{N}$ & Ortalama Puan & Standart Sapma \\
\hline $17-25$ & 494 & 55.55 & 14.37 \\
\hline $26-34$ & 21 & 59.38 & 16.65 \\
\hline 35-üzeri & 21 & 65.00 & 11.62 \\
\hline
\end{tabular}

Araştırmaya katılan öğrencilerin 17-25 yaş aralığında olanlar ile 26-34 yaş aralığında olanlar orta düzey okul iklimi algısı (45-64 puan aralığı) kategorisinde yer almaktadır. 35 ve üzeri yaş aralığında olan öğrenciler ise yüksek düzey okul iklimi algısı (65-85 puan aralığı) kategorisinde yer almaktadır. Öğrencilerin yaş aralıklarına göre puanları arasındaki farkın önem durumunu belirlemek için Levene testi uygulanmıştır. Test sonuçlarına göre $(\mathrm{p}>.05)$ grupların varyansı homojendir.

Tablo 11. Sağlık hizmetleri meslek yüksekokulu programları için tek yönlü varyans analizi sonuçları

\begin{tabular}{l|c|c|c|l|l}
\hline & Kareler Toplamı & sd & Kareler Ortalaması & F & p \\
\cline { 1 - 4 } Gruplar Arası & 2036 & 2 & 1018.0 & \multirow{2}{*}{4.931} & \multirow{2}{*}{.008} \\
\cline { 1 - 4 } Grup Içi & 110031 & 533 & 206.4 & & \\
\cline { 1 - 3 } Toplam & 112067 & 535 & 1224.4 & & \\
\hline
\end{tabular}

Varyans analizi sonucunda elde edilen $\mathrm{F}$ değeri 4.931 olarak hesaplanmıştır. $\mathrm{Bu}$ değer $\mathrm{p}<.05$ düzeyinde anlamlılık koşulunu sağladığı için öğrencilerin yaş değişkenine göre ortalama puanları arasındaki fark anlamlıdır.

Tablo 12. Tek yönlü varyans analizi (ANOVA) sonrası post-hoc Scheffe testi sonuçları

\begin{tabular}{l|c|c|c}
\hline $\begin{array}{l}\text { Yaş Aralığı } \\
(\mathbf{i})\end{array}$ & $\begin{array}{c}\text { Yaş Aralığı } \\
(\mathbf{j})\end{array}$ & Ortalama Farkı & p \\
\hline \multirow{2}{*}{$17-25$} & $26-34$ & -3.826 & .444 \\
\cline { 2 - 4 } & 35 ve üzeri & -9.445 & .009 \\
\hline $26-34$ & 35 ve üzeri & -5.619 & .402 \\
\hline \multicolumn{2}{l|}{.05 seviyesinde farkı anlamlı $p<.05$} \\
\hline
\end{tabular}

Tablo 12 incelendiğinde yaş grupları arasındaki en büyük farklılığın 17-25 yaş aralığı ile 35 ve üzeri yaş aralığı arasında olduğu anlaşılmaktadır. Yaş aralıkları arasındaki bu farklılık 35 ve üzeri yaş aralığı lehinedir.

\section{Sonuç ve Tartışma}

Okul iklimi, okuldaki insanlara bağlı olarak gelişen ve onların davranışları ile şekillenen bir kavramdır (Şahin, 2010). Bu araştırmada İstanbul'daki bir vakıf üniversitesinin meslek yüksekokulu ve sağlık hizmetleri meslek yüksekokulu öğrencilerinin okul iklimi algılarını belirlemek amaçlanmıştır. Öğrencilerin okula bağlılık, iletişim ve öğrenme ortamı faktörlerinden oluşan okul iklimi algıları incelenmiştir.

Araştırmada öğrencilerin okul iklimi ile ilgili algıları orta düzey okul iklimi algısı olarak kategorize edilmiştir. Benzer araştırma bulgusuna Saleh vd. (2018), üniversite öğrencilerinin okul algılarını inceledikleri bir araştırmada ulaşmıştır.

Araştırmada öğrencilerin öğrenim gördükleri yüksekokulu, okul ikliminin “iletişim” ve “öğrenme ortamı” faktörleri açısından yeterli buldukları sonucuna ulaşılmıştır. Öğrenciler öğrenim gördükleri yüksekokulun öğretim üyelerinin iletişiminden memnun olduklarını ifade etmiştir. Öğrenciler bir problemleri olduğunda öğretim üyelerine danışmaktan çekinmediklerini belirtmiştir. Ayrıca araştırmada öğrencilerin yüksekokullarını akademik açıdan yeterli bulduğu sonucuna ulaşılmıştır. Öğrenciler öğrenim gördükleri yüksekokulun kendilerine meslekleri ile ilgili bilgileri kazandırmada her türlü imkanı sağladığını ifade etmiştir. Öğrencilerin öğrenim gördükleri yüksekokulu akademik açıdan yeterli bulmaları okul iklimi açısından önemlidir. Çünkü MacNeil, Angus ve Steve (2009)'in ifade ettiği gibi sağlıklı öğrenme ortamı öğrencilerin akademik başarısını arttırdı̆̆ı gibi öğrencilerin okul iklimi algılarını da olumlu etkilemektedir.

Araştırmada, öğrencilerin öğrenim gördükleri yüksekokulu, okul ikliminin “okula bağlılık” faktörü açısından yeterli bulmadıkları sonucuna ulaşılmıştır. Ayrıca öğrenciler, öğrenim gördükleri yüksekokulu üniversite sınavına girecek öğrencilere önermediklerini ifade etmiştir. Öğrencilerin okula bağlılığı ile okul iklimi algıları arasında pozitif bir korelasyon vardır (Gündoğan ve Koçak, 2017). Olumlu okula bağlılık, öğrencilerin akademik başarısı, üniversitedeki sosyal ve kültürel faaliyetler ve öğretmenlerin mesleki yeterlilikleri ile ilgilidir (Erdoğdu ve Yüzbaş, 2018; Bülbül, 2012). Yüksek düzeyde okula bağlılığın, iletişımin, yeterli donanımın okul iklimi üzerine 
olumlu etkileri göz önünde bulundurularak (Gündoğan ve Koçak, 2017) yüksekokullara bağlılığını artırıcı faaliyetler önerilebilir; bina, sınıf, kafeterya, bahçe gibi fiziksel imkanların iyileştirilmesi; öğrenci kulüplerinin aktif çalışması, sanat ve spor etkinlikleri ve bilimsel geziler yapılması, öğretimin modern yöntem ve tekniklerle yapılması, öğretim üyelerinin mesleki yeterliliklerinin artırılması.

Araştırmada yüksekokul programları kendi içinde karşılaştırmalı olarak değerlendirilmiştir. Meslek yüksekokulu öğrencilerinin öğrenim gördükleri programa göre okul iklimi algıları arasında farklılık yoktur fakat sağlık hizmetleri meslek yüksekokulu öğrencilerinin öğrenim gördükleri programa göre okul iklimi algıları arasında bir farklılık vardır. "Optisyenlik” ve "iş sağlığı güvenliğì" programları öğrencilerinin okul iklimi algıları, "ameliyathane hizmetleri”, “odyometri”, "tıbbi dokümantasyon”, "tıbbi görüntüleme”, "tıbbi laboratuvar" programları öğrencilerinin okul iklimi algılarından daha yüksektir. Bu bulgular, sağlık sektörünün merkezinde yer alan programlarda (mezunlarının genellikle hastanede çalıştığı programlarda) öğrenim gören öğrencilerin sağlık hizmetleri meslek yüksekokulunu okul iklimi açısından yetersiz bulduğu şeklinde yorumlanmıştır. Bu programlarda öğrenim gören öğrencilerin okul iklimi algılarını artırmak için okul atmosferinin sağlık okulu atmosferine dönüştürülmesi önerilmektedir. Bunun için üniversite bünyesinde sağlık bilimleri, tıp ve diş hekimliği fakülteleri gibi diğer sağlık okullarının açılması önerilebilir. Ayrıca öğrencilerin staj ve klinik uygulama öğretimlerine verilen önem artırılabilir.

Araştırmada, Saleh vd. (2018)'nin ulaştığı sonuca benzer şekilde öğrencilerin okul iklimi algılarının sınıf düzeyi arttıkça azaldığı tespit edilmiştir. Bu bulgu, yüksekokula dışardan gelen öğrencilerin okul iklimi algılarının iyi olduğunu, öğrencilerin öğrenimi sırasında karşılaştığı olumsuz durumlar nedeni ile okul iklimi algılarının azaldığı şeklinde yorumlanmıştır. Buna ek olarak öğrencilerin öğrenim gördükleri yüksekokul ile ilgili okul iklimi algılarının öğrencilerin yaşı artıkça arttığı sonucuna ulaşılmıştır. Benzer araştırma sonucuna Şamdan ve Baskan (2019) tarafından da ulaşılmıştır. Okul iklimi ile öğrencilerin yaşları arasındaki bu ilişki, araştırmanın yapıldığı üniversitenin yüksekokullarına gelen yaşları büyük öğrencilerin çoğunlukla bir mesleğe sahip olmaları ile ilişkilendirilmiştir. Mesleki kaygıları olmayan bu öğrenciler genellikle okuldaki sosyal ortama dahil olmamaktadırlar. Bu nedenle bu öğrencilerin yüksekokuldan beklentileri yalnızca akademik yeterlilik olmaktadır. Bununla birlikte yüksekokula gelen yaşı küçük öğrenciler çoğunlukla bir mesleğe sahip olmadıkları için mesleki kaygı taşımaktadır ve okuldaki sosyal ortama dahil olmaktadırlar. Bu nedenle bu öğrenciler yüksekokullarını okul iklimi açısından değerlendirirken akademik ortamın yanı sıra diğer etkenleri de dikkate almaktadır.

Vakıf üniversitelerinin meslek yüksekokullarında çalışan öğretim üyeleri, öğrencilerin kurumlara öğretim ücreti ödemesinin de etkisi ile öğrencileri ile iyi iletişim kurmaktadır. Bu kurumlardaki yöneticiler de öğretim üyelerinin öğrencileri ile olan iletişimine önem vermektedir. Buna karşılık vakıf üniversitelerinin bir bölümünün fiziksel ve sosyal olanakları yetersizdir. Bu üniversitelerin meslek yüksekokullarının çoğunlukla bir kampüsü bulunmamaktadır ve öğretim yaptıkları binaların sosyal olanakları ve altyapıları yetersizdir. Alanyazındaki diğer araştırmaların ve bu araştırmanın sonuçları ışı̆̆ında yapılan okul iklimini artırıcı öneriler, Türkiye'deki tüm vakıf üniversitelerinin yüksekokullarına genellenebilir.

Araştırmacılara, bu araştırmaya benzer bir araştırmayı bir devlet üniversitesinin yüksekokullarında öğrenim gören öğrenciler ile yapmaları önerilmektedir. Vakıf ve devlet üniversitesi yüksekokullarında yapılacak okul iklimi algısı araştırması bulguları ışı̆̆ında Türkiye'deki tüm yüksekokullar için okul iklimini artırıcı öneriler oluşturulabilir.

\section{Kaynakça}

Akkuzu Güven, N. and Uyulgan, M. A. (2019). Analitik kimya laboratuvarında sorgulama temelli sistematik kalitatif katyon analizi deneylerinin bilimsel süreç becerilerine yansıması. Avrupa Bilim ve Teknoloji Dergisi, (17), 423-436.

Bektaş F. ve Nalçacı B. (2013). Okul iklimi ile öğrenci başarısı arasındaki ilişki. Uluslararası Avrasya Sosyal Bilimler Dergisi, 4 (13), $1-13$.

Bocchi B., Dozza L. and Cavrini G. (2013). School climate: comparison between parents' and teachers' perception. Procedia-Social and Behavioral Science 1, 116(21), 4643-4649.

Bülbül T., (2012). Okul yöneticilerinin yenilik yönetimine ilişkin yeterlik inançları. Trakya Üniversitesi Sosyal Bilimler Dergisi. 14(1), 45-68.

Uğurlu C. T (2017). Okul Yönetimi, ANI Yayıncılık, Ankara.

Doğan S. (2012). Lise öğrencilerinin okul iklimi algıları. Adıyaman Üniversitesi Sosyal Bilimler Enstitüsü Dergisi, 10(2), 55-92.

Ekşi H., Türk T. ve Avcu A. (2017). Maryland güvenli ve destekleyici okul iklim ölçeği (MGDOI)'nin türk kültürüne uyarlanması: geçerlik ve güvenirlik çalışması. Abant İzzet Baysal Üniversitesi Eğitim Fakültesi Dergisi, 17(4), 1882-1899.

Erdoğdu, M.Y. ve Yüzbaş, D. (2018). Lise öğrencilerinin okula bağlılık ile genel öz-yeterlilik düzeyleri arasındaki ilişki. Süleyman Demirel Üniversitesi Sosyal Bilimler Enstitüsü Dergisi, 3(32), 205-227.

George, D. and Mallery, M. (2010). SPSS for Windows Step by Step: A Simple Guide and Reference (10. ed.), Boston: Pearson.

Gündoğan A. ve Koçak S. (2017). Öğretmen adaylarının okul iklimi algıları ile akademik öz-yeterlik inançları arasındaki ilişkinin incelenmesi. Sakarya University Journal of Education, 7(3), 639-657.

Haynes, N. M., Emmons, C. and Ben-Avie, M. (1997). School climate as a factor in student adjustment and achievement. Journal of Educational \& Psychological Consultation, 8(3), 321-329.

Karakütük K., Binali T., Tuncer B., Güven Ö. ve Murat T. (2014). Genel Ortaöğretim Okullarının Büyüklüğü ile Okul İklimi Arasındaki İlişkinin İncelenmesi. Eğitim ve Bilim, 39(171), 304-216.

Kilıç, S. (2013). Örneklem Yöntemleri. Journal of Mood Disorders, 3(1), 44-46.

Kılınç A.Ç. (2014). Examining the relationship between teacher leadership and school climate. Educational Sciences: Theory and Practice, 14(5), 1729-1742.

MacNeil, D.L., Angus J.P. and Steve B. (2009). The effects of school culture and climate on student achievement. Interntional Journal of Leadership in Education: Theory and Practice. 12(1). 73-84.

e-ISSN : 2148-2683 


\section{European Journal of Science and Technology}

Mitchell, M. M., Bradshaw, C. P. and Leaf, P. J. (2010). Student and teacher perceptions of school climate: a multilevel exploration of patterns of discrepancy. Journal of School Health, 80(6), 271-279.

Özdemir S., Sezgin F., Sirin H., Karip E. ve Erkan S. (2010). İlköğretim okulu öğrencilerinin okul iklimine ilişkin algılarını yordayan değişkenlerin incelenmesi. Hacettepe Üniversitesi Eğitim Fakültesi Dergisi. 38, 213-224.

Pritchard, R. J., Morrow, D. and Marshall, J. C. (2003). School and district culture as reflectedin student voices and student achievement: school effectiveness and school improvement. An International Journal of Research, Policy and Practice, 16 (2), $153-177$.

Saleh M., Arabiat D., Shaheen A., Nassar O. and Mansour A. (2018). Social and health determinants of adolescents' wellbeing in jordan: 1mplications for policy and practice. Journal of Pediatric Nursing, 39, 55-60.

Şamdan T. ve Baskan G. (2019). Öğretmenlerin Algılarına Göre Örgütsel Adalet ve Örgütsel Sinizm Arasındaki İlişkinin İncelenmesi. Pamukkale Üniversitesi Eğitim Fakültesi Dergisi, 47, 17-40.

Saraç K. (2015). Okul İkliminin Ortaokul Öğrencilerinin Algılarına Göre Değerlendirilmesi. Eskişehir Osmangazi Üniversitesi Eğitim Bilimleri Enstitüsü Eğitim Bilimleri Anabilim Dalı Eğitim Yönetimi, Teftişi, Planlaması ve Ekonomisi Bilim Yüksek Lisans Tezi, Eskişehir.

Şahin A. (2010). Örgüt kültürü-yönetim ilişkisi ve yönetsel etkinlik. Maliye Dergisi, 159, 21-35.

Şenel T. ve Buluç B. (2016). İlkokullarda okul iklimi ile okul etkililiği arasındaki lişki. TÜBAV Bilim Dergisi, 9(4), 1-12.

Terzi, A.R. (2015). Üniversite öğrencilerine yönelik okul iklimi ölçeğinin geliştirilmesi. Eğitim ve Öğretim Araştırmaları Dergisi, 4(4), $111-117$

Tofur S. ve Balıkçı A. (2018). Okul yöneticileri ve öğretmenlere göre okul iklimini etkileyen faktörlerin incelenmesi: ortaokul örneği. Turkish Studies Educational Sciences, 13(11), 279-1295. 